\title{
A NEW SPECIES OF ISSIKIELLA FROM THE AMAZON BASIN
}

(Mecoptera: Bittacidae)

\author{
Norman D. Penny * \\ Jorge R. Arias *
}

\section{Abstract}

A new species of Issikiella is described from southern Pará State, Brazil, and compared with the other two known species.

\section{INTRODUCTION}

The genus Issikiella was described by Byers (1972) to include a species, Issikiella pulchra, from southern Brazil and another (undescribed) from southern Bolivia. Penny and Arias (1982) described one further species from central Amazonia and recorded one further locality for the genus, Belém, near the mouth of the Amazon. During a recent collecting trip to the middle Rio Araguaia, a further new species was collected near Conceição do Araguaia, approximately $750 \mathrm{~km}$ south of Belém in southern Pará State. Thus, the present distributional data indicate that the genus issikiella has a broad range encompassing most tropical and subtropical forests of South America, south of Venezuela and east of the Andes.

\section{KEY TO MALES OF ISSIKIELLA}

1a. Cerci not exterding to base of dististyles; without mesal projections at dorsal and ventral margins of epiandrial lobes, but mesal projection on central surface; apex of epiandrial lobes acutely pointed at caudo-ventral margin ...... I. pulchra

1b. Cerci extending to base of dististyles or beyond; mesal projections at dorsal and ventral margins of epiandral lobes but not on central surfa- ce; apex of epiandrial lobes obtusely rounded at caudo-dorsal margin

2a. Ventral projection of epiandrial lobe elongate-triangular, with small acute lobe at its anterior base; dorsal projection of epiandrial lobes wider than long. . . . I. araguaiensis

2b. Ventral projection of epiandrial lobe broadly quadrate, without small basal lobe; dorsal projection of epiandrial lobe as long as or longer than wide. . . . . . . . I. byersi

\section{ISSIKIELLA ARAGUAIENSIS Penny \& Arias, n. sp. \\ (Figs. 1-3)}

Original description based on 13 males, 16 females, pinned.

Head: Clypeus, vertex and occiput pale brown; rostrum and ocellar triangle dark brown. Rostrum slender, labrum about five times as long as its width at base; maxillary and labial plaps dark brown, darker than other rostral elements. First segment of maxillary palp with long sensory hair. Terminal (fifth) segment of maxillary palp about same length as fourth. Eyes brown, separated in front by distance about equal to width of base of labrum, and width of ocellar triangle. Antennae short labout $3.0 \mathrm{~mm}$ in both sexes), very slender, each comprising elongate scape and ovoid pedicel and apparently 18 thin, cylindrical flagellomeres (segmentation obscure beyond 10th flagellomere); hairs on apical segments about four times as long as diameter of flagellomeres.

\footnotetext{
* Instituto Nacional de Pesquisas da Amazônia, Manaus.
} 
Thorax: Notal and pleural areas pale brown, becoming yellowish-brown near legs; generaliy glabrous, with almost no pilosity. Femora and tibiae yellowishbrown with a few scattered black spines; femora darkened at apices; tibiae only slightly darkened at tips, basitarsi dark yellowish brown grading into brown on more distal tarsomeres. Hind femur not enlarged, of more or less uniform diameter throughout in both sexes. Hind tarsus not conspicuously enlarged in male.

Wings: highly iridescent, clear dark yellow from base to origin of $M$ and in cells. $C$ and Sc to stigma, veins dark brown; stigma intense dark brown, large, extending from anterior wing margin to vein $\mathrm{R}_{2}+3$, color continuing on crossveins and at apex of branches of $R$ and $M$, beyond last crossvein; additional spots of brown at origin of Rs, first fork of Rs, origin of $M$, end of $\mathrm{Cu}_{2}$, in cells $R$ and $M$, around both thyridia and along proximal crossveins. Subcosta extending well beyond origin of Rs (ORs), joining $C$ just before level of first fork of Rs; Scv just beyand ORs. Vein $R_{2}+3$ not deflected backward at Rcv. In front wing, vein $1 \mathrm{~A}$ extends slightly beyond level of humeral crossvein (h), 2A ends just before level of $h$; apical crossvein present near end of $1 A$, another near end of $2 A$; vein $3 A$ not present. In hind wing, $1 A$ coalesces with $\mathrm{Cu}_{2}$ for most of its length, turning to posterior wing margin as crossvein beyond level of $h$. Vein $2 A$ very small, difficult to distinguish. Only one pterostigmal crossvein, near proximal end of stigma, joining $R_{2}+3$ just beyond first cell $R_{3}$.

Abdomen of Male: Segments 2 through 8 dark brown dorsally, yellowish brown ventrally; segments 7 and 8 much darker dorsally than preceding segments. Fused basistyles dark brown; epiandrial lobes translucent yellow. Epiandrial lobes elongate, with apex obtusely rounded at caudo-dorsal margin (Fig. 1); a mesally directed spiniferous point on dorsal margin approximately two-thirds distance to tip (Fig. 2) wider than long; a mesally directed, subapical, setiferous projection on ventral margin apically rounded, with small lobe at anterior base; numerous small, black denticles along mid-dorsal margin. Basistyles fused along entire length, without median membranous area. Dististyles relatively large, mesally-directed. Proctiger with a simple dorsal plate. Cerci slender, elongate, extending well beyond apex of basistyles. Aedeagus slender, only slightly enlarged at base, apparently only once coiled.

Abdomen of Female: Segments 2 to 8 uniformly dark brown, slightly enlarged posteriorly. Anterior margin of 9th and 10th terga forming more heavily sclerotized crescentic marks. Ninth sternum bearing membranous indentation, with heavily sclerotized and pigmented spot at apex (Fig. 3). Cerci quite long and slender, gradually tapering to point.

Body Length: male, 12.1 - 14.8 $\mathrm{mm}$; front wing, $14.0-15.0 \mathrm{~mm}$. Body length of female, $14.0-14.2 \mathrm{~mm}$; front wing, $14.5-15.0 \mathrm{~mm}$.

Types: Holotype male, allotype female and 27 paratypes collected at Morro da EMBRATEL, $7 \mathrm{~km}$ west of Conceição do Araguaia, 19-I-4-II-1983, N. D. Penny, J. A. Rafael, A.Y. Harada, J.E.B. Brasil, and R.N.L. Santos collectors. Holotype, allotype, and some paratypes in the Systematic Entomology Collection of INPA. Other paratypes in Museu Paraense Emílio Goeldi, Belém; Museu Nacional, Rio de Janeiro; Museu de Zoologia, Univ. de São Paulo, São Paulo: Depto. de Zo. ologia, Univ. Fed. de Paraná, Curitiba; British Museum (Natural History), London; Smithsonian Institution, Washington; Snow Entomological Museum, Univ. of Kansas, Lawrence; and Natal Museum, Pietermaritzburg, South Africa.

Habitat: This species was fairly abundant at the base of a low, forested moutain, near Conceição do Araguaia. This is one of the few areas in the region which has retained its original forest ve- 


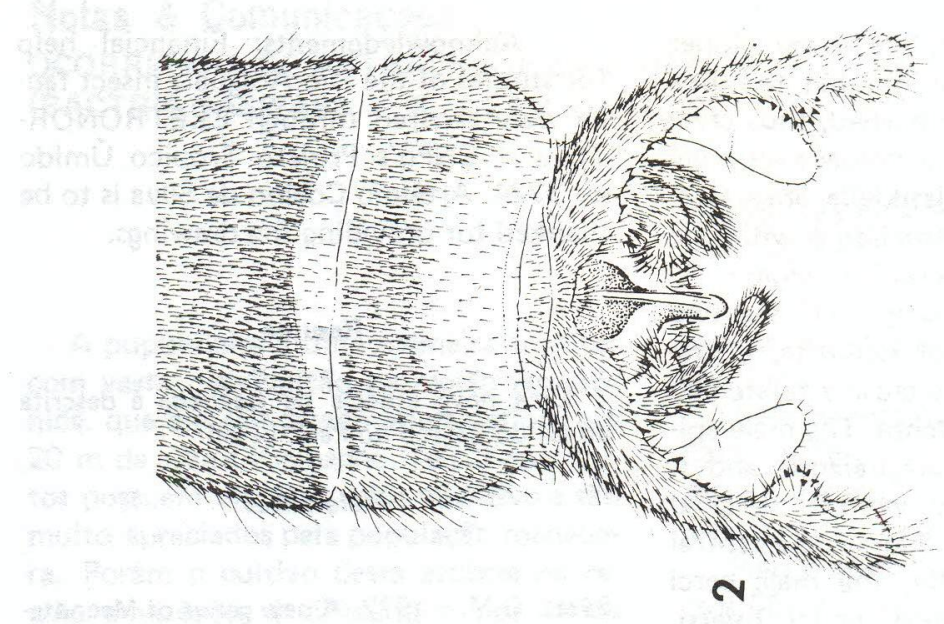

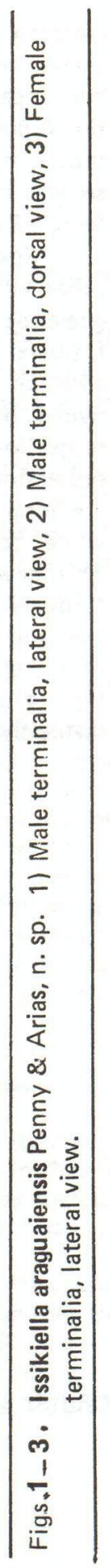


getation. However, on the lower slopes there was some indication that the area had occasionally been burned, thus creating a great deal of low, herbaceous vegetation, mostly ferns. Issikiella araguaiensis was collected in association with one female Pazius (Mecoptera: Bittacidae).

Species Relationships: Of the two other known species of Issikiella, I. araguaiensis is much more closely related to I. byersi than to I. pulchra. The male epiandrium of both $\mathrm{I}$. araguaiensis and $\mathrm{I}$. byersi has dorsal and ventral marginal projections, while I. pulchra has a central projection. Additionally, the male cerci are long in I. araguaiensis and I. byersi, while being quite short in I. pulchra. This new species can be separated from I. byersi by the shorter dorsal projection and more elongate ventral projection of the epiandrial lobes, the simpler proctiger, shorter aedeagus, and in females the distinctive spot on the ninth sternum.
Acknowledgments: Financial help for studies of the Rio Araguaia insect fauna were secured through ELETRONORTE and CNPq's Projeto Trópico Úmido no 3224. Artêmio Coelho da Silva is to be thanked for providing the drawings.

\section{Resumo}

Uma nova espécie de Issikiella é descrita do sul do Estado do Pará, Brasil.

\section{References}

Byers, G.M.-- 1972. A new genus of Mecoptera from Brazil. J. Kans. ent. Soc., 45(3) : $340-346$.

Penny, N.D. \& Arias,J. R. - 1982. Notes on Amazonian Bittacidae (Mecoptera) with the descriptions of two new species. Mem. Inst. Oswaldo Cruz, 77(3): 263--274.

(Aceito para publicação em 23/10/83) 